\title{
SURFACE WANDERINGS OF FOSSORIAL MAMMALS
}

\section{By A. Brazier Howell}

The writer had always thought it an accepted theory that certain fossorial mammals move about on the surface of the ground to some extent, but recent enquiry among mammalogists has brought to light considerable skepticism on this point. Published proof is meager, and the most conclusive evidence that has yet appeared seems to be that presented by Dr. H. B. Bryant (Univ. Calif. Pub. Zool., XII, 2, 1913, pp. 25-29), who found a number of gophers that had been caught in a gutter full of tar. It may be argued that these animals were forcibly driven from their burrows by a flood of irrigation water; but, under the circumstance, it is more likely that the advance of the dry season had rendered the soil in which they were working too hard for their taste, and that they were seeking new pastures.

For ten years I lived on my orange grove at Covina, Los Angeles County, California, where gophers (Thomomys bottce pallescens not typical) were so common that I have taken 300 on ten acres within six months. During the greater part of the year the ground was scrupulously and finely cultivated, and not a weed allowed to grow; hence, gopher mounds were readily found as soon as formed. One of our chief cares was to find every one of these animals that entered the grove from the surrounding territory and catch it at once. As there were no other growing things, each gopher invariably made for an orange tree to feed on the tender bark of the roots, and if he happened to strike and girdle the tap root, sixty dollars worth of damage was done. So one may well believe that we exercised the utmost vigilance to keep the grove free from these pests, and except during the winter, when a leguminous cover crop was grown, mighty few gophers remained undetected upon the ranch for more than twenty four hours. For this reason, it was impossible for a gopher to work its way, underground, into the center of the grove before it was discovered. They habitually entered from a piece of uncultivated land on the south; from a pasture on the east, for the most part unirrigated; and from the weedy borders of a highway on the west. Of course, the usual mode of entry to the property was by short extensions of the burrows until the boundary was crossed, but in at least two score instances, their workings suddenly appeared from a few yards to as much as 380 feet from the nearest cover. And at that, they traveled over bare ground, where, one would imagine, there would be slight attraction to lead them on. Six or eight 
times we have, when attending at night to some such activity as fumigation, encountered lone animals meandering about through the trees and far from any possible burrow. Nor have I taken into account those animals found on the move during the monthly irrigation, for then they are flooded out and will make for the nearest dry ground.

On my ranch near Calexico, Imperial County, California, the pale Thomomys perpallidus albatus is abundant, but in this locality the gophers live only in the banks of the larger irrigation ditches, where they are at all times out of reach of flooding. They never enter the fields for more than a few feet, for in summer these are thoroughly irrigated at least every ten days and sometimes oftener. My foreman is occupied with irrigating a great deal during the night, and he informs me that he often finds gophers wandering about well away from burrows, and in situations that would preclude the possibility that they had been flooded out.

The habit of albatus in apparently instinctively shunning ground that will shortly be flooded is worth noting in comparison with that of the Covina animal, which latter will readily seek the lowest spots, from which they are regularly driven by water. Under original conditions, pallescens was never troubled by too much water, except in very rare conditions, as when a cloudburst would drive a few unlucky animals onto higher ground. On the other hand, albatus was originally confined to the bottom lands along the lower Colorado River. At stages of low water the most attractive habitat was undoubtedly the lower association close to the river, as the herbage there would be of a more luxuriant character. However, such animals as obeyed this urge would invariably be flooded out and drowned by the annual high water conditions. Hence, along the river, they seem to be, or rather, they were, a number of years ago, found only in those situations that are seldom or never subject to such perils. In the recent extension of range of these animals into the Imperial Valley, their movements are apparently actuated by the same caution in regard to water. Call it instinct or what you will.

It is well known that pocket gophers will make excursions of several feet from their burrows, even in the daytime, after especially attractive food, but they usually prefer to burrow under their larder, and will thus hollow out a large squash or pumpkin from beneath, leaving no external signs of the depredation. Very young animals are sometimes observed sunning themselves near the entrances to the tunnels in the most unconcerned manner, but such actions are probably due more to curiosity than to anything else. 
It seems to be the accepted theory that most of the surface traveling indulged in by gophers is undertaken by old males in search of mates. However, while the males will undoubtedly seek out the females, either below or above ground, by far the majority of proven cases of emigration of which I know have consisted either of females or of half grown animals. The old males, being larger (in many forms) and better fitted to cope with adverse conditions, such as hard digging through the drying soil for a failing supply of food, are probably more prone to remain in one spot than are the smaller, weaker individuals. At any rate, but few pocket gophers elect to live in bone-dry ground. It is true that they often make short excursions into it, but in almost all cases the main runways are in soil with some indications of subsurface moisture. During the old days before the advent of the white man into the ranges of many of the lowland gophers in California, conditions entirely propitious for the presence of these animals occurred in somewhat restricted, and often scattered, areas, as small stretches of grass along the upper washes, or around the border of a cienaga. These spots were frequently separated from each other, sometimes by considerable distances, and at other times by little rocky ridges only a few yards across. If the animals traveled only underground, they then would frequently be confined to the immediate vicinity of their birthplaces, and inbreeding would soon occur, with consequent deterioration of stock and even extermination in small areas, which could not subsequently be restocked. Hence, the ability and incentive for overland traveling is of considerable importance to many members of the genus.

Very few pocket gophers have been taken in surface traps, probably for the reason that the ordinary mouse trap is too weak to hold such an animal. The present writer uses a home-made, wooden-base trap of the usual pattern, but the spring has almost twice the pull of the ordinary, factory-made product, and the part that secures the animal measures two and a quarter inches each way. These obtain greater results, for I have taken three small gophers in them, baited with oats, and with no burrows nearby. Even this trap is, of course, entirely inadequate for large or medium-sized animals.

The same contention obtains for moles: the ordinary mouse trap is out of the question, and even my larger ones can hold the smallest animals only when the trap can kill them instantly by smashing the skull. After the following manner I have caught three individuals of the coast mole (Scapanus orarius orarius) in oat-baited traps. 
A specimen June 23, 1919, near Hardy, Mendocino County, California, in a trap set beneath a log, which latter was several inches above the ground for a distance of three feet. There was no sign of an open burrow within eighteen inches of the trap in either direction. 


\section{$2 \mathrm{BHL}$ Biodiversity Heritage Library}

Howell, A. Brazier. 1922. "Surface Wanderings of Fossorial Mammals." Journal of mammalogy 3, 19-22. https://doi.org/10.2307/1373447.

View This Item Online: https://www.biodiversitylibrary.org/item/220041

DOI: https://doi.org/10.2307/1373447

Permalink: https://www.biodiversitylibrary.org/partpdf/90537

\section{Holding Institution}

Smithsonian Libraries

\section{Sponsored by}

Biodiversity Heritage Library

\section{Copyright \& Reuse}

Copyright Status: Not in copyright. The BHL knows of no copyright restrictions on this item.

This document was created from content at the Biodiversity Heritage Library, the world's largest open access digital library for biodiversity literature and archives. Visit BHL at https://www.biodiversitylibrary.org. 